\title{
Using Serious Game in Sustainable Global Manufacturing Education
}

\author{
Borzoo Pourabdollahian Tehran, Marco Taisch, and Manuel Fradinho \\ Department of Management, Economics and Industrial Engineering, \\ Politecnico di Milano, Milan, Italy \\ \{borzoo. pourabdollahian, marco.taisch, manuel. fradinho\} @polimi.it
}

\begin{abstract}
Having multi-skilled engineers who can master the complexity associated to sustainable manufacturing is a strategic requirement for manufacturing companies wanting to compete in the global market. The current approaches to manufacturing education and training, both at university and at industry, need to be revisited to improve the learning effectiveness of manufacturing engineers. An important factor in the learning effectiveness is the delivery mechanism and recently Serious Game (SG) is a promising suitable supplementary method to enhance the learning experience in engineering schools and industry.
\end{abstract}

Keywords: Serious Games, Sustainable Global Manufacturing.

\section{Introduction}

The manufacturing industry continues to grow due to globalization, customized products, green production, etc. However, there is a paradigm shift where cost is no longer the driving factor in the industry, with the social and environment increasing in importance for driving the business. This brings a challenge to the education and training, in particular with regards to higher education, because engineering schools are regarded as the supplier of future qualified engineers and consequently are responsible to transform students into graduates who are practitioners capable of ensuring sustainable manufacturing (Sibbel, 2009).

The advent of SGs brings the promise of a novel instructional method to manufacturing and engineering education. The use of SGs provides the opportunity of situated learning, where the learner is emerged in the actual context and therefore increasing the retention rate whilst improving the potential for transformation of the learner. There is growing evidence of the relevance and impact of SG in education in various domains, such as health, business, cultural heritage, etc. However, the same cannot be said with regards to engineering and manufacturing in particular. McLean et al., (2005) conducted a study to understand whether video games technology can be useful in manufacturing education. The result demonstrated both, significant advantages in learning process and also students' interest with learning by playing. 
Sustainable Global Manufacturing (SGM) game has been designed based on the innovative Technology Enhanced Learning (TEL) platform developed within the context of the TARGET ${ }^{1}$ project. Sustainable manufacturing involves broadly lifecycle stages from pre-manufacturing to end consuming and consequently several partners get involved to manage at each of these stages. Therefore, knowing environmental impacts on end product, which can be identified by Life Cycle Assessment (LCA), is quietly essential. This game aims to improve learners' competence in sustainable manufacturing by performing LCA tool.

In this study a SG focused on Sustainable Global Manufacturing was evaluated based on teachers' perspective who taught in department of industrial engineering at Politecnico di Milano. 16 teachers participated in a study where they played the first version of the game (0.41.04) and then, each individually took part of a deep interview in which they responded to 23 questions. The results demonstrated that SGM has strong potential for adoption by the teachers in their classes. In addition they highlighted the ability of game to enhance social and personal skill of engineers apart from acquired knowledge about sustainable manufacturing, even though they believed SG attributes have not integrated well at SGM yet.

\section{Relation to the Existing Theories and Works}

SGs may belong to any category (e.g. Health, Business, Military, etc.) and they are being considered as a way of edutainment They are designed as virtual environments which plainly have the intention of education or training with two key attributes; being educative and immersive (Poplin, 2012). In manufacturing education, Hague et al (2010) stated that SGs can be extremely successful while teaching sustainability to engineers, because they facilitate the acquisition of not only technical skills, but also soft skills like collaboration, creativity and communication.

SGs attributes are borrowed from computer games, while they are blurred to instructional concepts in order for make education and entertainment simultaneously. So far, some prominent studies have been done to identify SGs attributes (Charseky, 2010; Gariss et al., 2002; Asgari and Kaufman, 2009; Gunter et al., 2007). In the Table 1, five attributes of SGs and their performance indicators, those are relevant to manufacturing education, are identified.

On the other hand, the effectiveness of SGs to enhance the learning outcomes is usually under discussion, and significant efforts have been done so far to define relevant indicator to measure the learning outcomes. They are mostly presented as a design or evaluation frameworks. Prominent ones obviously pinpoint the importance of considering not only engineering knowledge, but also professional skills. The latter is extremely demanded by industry in order to employ engineers who are able to work at dynamic environment. See table 2.

\footnotetext{
${ }^{1}$ TARGET (Transformative, Adaptive, Responsive and enGaging EnvironmenT) was an integrated project funded by EU, which concluded in October 2012.
} 
Table 1. Attributes of SGs and their performance indicators for manufacturing and engineering education

\begin{tabular}{|c|l|}
\hline $\begin{array}{c}\text { Rule and } \\
\text { Goal }\end{array}$ & $\begin{array}{l}\text { Identifying winning conditions, providing various ways to achieve goals based } \\
\text { on players action and specific situations, defining clear goals and rules, identi- } \\
\text { fying specific learning outcomes, providing different kinds of feedbacks (con- } \\
\text { structive, clear and frequent). }\end{array}$ \\
\hline $\begin{array}{c}\text { Sensory Sti- } \\
\text { muli }\end{array}$ & $\begin{array}{l}\text { Providing a virtual manufacturing and engineering process in similar to reality, } \\
\text { and integrating fantasies attributes to learnt material (visual and sound effects, } \\
\text { colors and graphics). }\end{array}$ \\
\hline Control & $\begin{array}{l}\text { Providing a responsive learning environment, providing different level of } \\
\text { choices, making a sense of control among players, providing different kind of } \\
\text { solutions to solve problems, permitting learners to produce powerful effects. }\end{array}$ \\
\hline Challenge & $\begin{array}{l}\text { Producing multiple levels of goals, providing an optimal level of information } \\
\text { and using hidden information, providing positive feedbacks to promote feeling } \\
\text { of competence. }\end{array}$ \\
\hline Interactivity & $\begin{array}{l}\text { Using game mechanics regarding communication (e.g. dialogue tool) to im- } \\
\text { prove the professional skills (negotiation, active listener, conflict, etc.). Provid- } \\
\text { ing optimum level of competition (i.e. neither boring nor anxious). }\end{array}$ \\
\hline
\end{tabular}

Table 2. Description of three frameworks to design and evaluate SGs

\begin{tabular}{|c|l|}
\hline Krikpartck & $\begin{array}{l}\text { There are identified four aspects to evaluate learning outcomes where } \\
\text { three of them are related manufacturing. Reaction" resembles to what } \\
\text { extent players' satisfaction is supported by game which is a point under } \\
\text { special attention because of some complicated course at this domain. } \\
\text { "Knowledge change" is a critical point to teach contemporary demanding } \\
\text { skills at engineering education such as communication and team working. } \\
\text { SGs are expected to moderately enable players to transfer acquired engi- } \\
\text { neering knowledge in a reality. This is named "Transfer ability" here. }\end{array}$ \\
\hline $\begin{array}{c}\text { Gearning- } \\
\text { GBL Evalua- } \\
\text { tion Frame- } \\
\text { work (Hainey, } \\
\text { 2010) }\end{array}$ & $\begin{array}{l}\text { This focuses on both teachers and learners to design SGs. Among seven } \\
\text { main aspects, motivation, preferences and collaboration are fully in rela- } \\
\text { tion to engineering education. Considering motivation elements can } \\
\text { stimulate players to be involved and, at higher level, to be engaged the } \\
\text { method and also considering students preference to play the game in } \\
\text { which context (e.g. at class, home, etc.) are essential parts of game de- } \\
\text { sign. Communication can strongly impact on learning effectiveness. The } \\
\text { ability of students to work as a team member and deal with happening } \\
\text { challenges (decision making, conflict, etc.) at industry is pinpointed }\end{array}$ \\
\hline $\begin{array}{c}\text { Four Dimen- } \\
\text { sional Frame- } \\
\text { work-FDF (de } \\
\text { Freitas and } \\
\text { Oliver, 2006) }\end{array}$ & $\begin{array}{l}\text { This concentrates both on tutors and learners. "Context" represents where } \\
\text { the game can be run to be useful, the structure of its application and how } \\
\text { it is supported by technical tools. "Mode of representation" is greatly } \\
\text { necessary to take consider at design SGs in the domain. Players should } \\
\text { feel optimum level of immersion, fidelity and interactivity generated by } \\
\text { game attributes and supportive discussion before and after play. }\end{array}$ \\
\hline
\end{tabular}




\section{$3 \quad$ Methodology}

In this study we evaluate the Sustainable Global Manufacturing (SGM) scenario of the TARGET platform. The scenario provides a situated learning context for engineering students to learn SGM concepts, with focus on "communication and negotiation skills"; "system thinking"; "ability to see the big picture"; "short versus long term strategies" and "critical thinking". In the game scenario the player is assigned as a Sustainability Manager of an internationally operating manufacturing company. The company produces household appliances such as coffee machines. He needs to deal with different challenges to acquire the main goal, delivering green products to the market. In this situation, he is expected to fill in Life Cycle Assessment tool regarding not only his own background, but also taken information from three none playercharacters. CEO, Production manager and Shift manager.

In this study two research questions have been addressed to reveal teachers' point of views about SGM effectiveness at PLM (Product Lifecycle Management) course.

- RQ1: How well SGs attributes are integrated in SGM?

- RQ2: To what extent learning outcomes can be achievable by playing SGM?

A deep study was designed to answer these research questions in which 16 teachers from industrial engineering group of DIG (Dipartimento Ingeneria Gestionale) at Politecnico di Milano participated. At first, they took part at briefing session to be introduced with game scenario, content and structure. Then a game session was run where they played the first version (0.41.04) of the SGM. At the end each teacher individually was requested for a deep interview to gather data to respond the research questions. In order to prevent missing any data, all interviews were recorded with respect to their permission.

To answer first research question, we employed attributes extracted from literature review at section two (see table 1). Teachers completely were informed about the practical definition of each attribute and then they were questioned to recognize those were integrated at game. By considering expected learning outcomes "Positive reaction", "Information gathering", "Performing LCA", "Decision making", "Transferability", and "Supportive method" were identified to be asked so that teachers explain to what extent each learning outcome can be supported by SGM.

\section{$4 \quad$ Results}

\subsection{How Well SGs Attributes Are Integrated in SGM?}

Analyzing collected data about the serious game attributes demonstrated that the score being 0,55 out of 1(see figure 1). "Rules and Goal" and "Interactivity" were mostly selected (12 out of 16), in versus just 4 participants felt "Sensory Stimuli". Teachers mostly, around $63 \%$, expressed that there was not a specific objective to be controlled. For instance sometimes players are perverted by given wrong information from non-player characters, but there is not any mechanism (e.g. feedback) to inform them so that they are able to correct their performance at a right direction. However, teachers admired SGM to presents rules and goals clearly as well as its ability to 
provide an interaction environment in which the player needs to communicate and negotiate efficiently with NPCs in order to complete LCA tool. Being some contradiction ideas was a noticeable point at deep interviews. For instance, one participant believed that game attributes are integrated well, “...I have seen Rules \& Goals when I saw the order of things that you have to do, for instance start with talking to CEO, then go to production manager, and so on. Challenge exists when you try to find the right person who can explain things better..." even though another teacher oppositely believed attributes were not clear at the game, “...There do not seem to be much challenge because everything is predefined already. I do not think also that this game has clear rules and goals feature because there are not many options unlike in good serious games..."

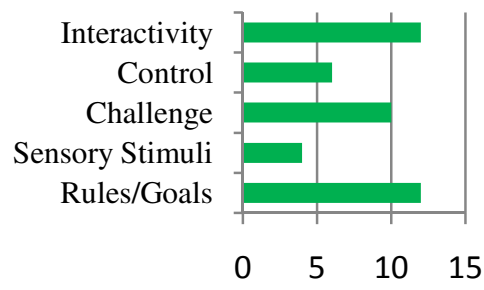

Fig. 1. Results of essential game features

\subsection{To What Extent Learning Outcomes Can Be Achievable by Playing SGM?}

In deep interviews participant were asked by 13 questions to uncover to what extent learning outcomes are achievable by playing SGM. In Table 2 questions are identified and for each a short abstract of two or three teachers' point of views is shown.

Table 3. List of questions used to measure to what extent learning outcomes can be achievable, and a short abstract of some answers

\begin{tabular}{|c|c|}
\hline Questions & Answers \\
\hline $\begin{array}{l}\text { Do you think students would } \\
\text { reflect positively and enjoy explor- } \\
\text { ing the virtual environments and } \\
\text { interacting with the game charac- } \\
\text { ters? }\end{array}$ & $\begin{array}{l}\text { "Yes, they will enjoy but maybe it is not successful."(P5) } \\
\text { "It needs to be more interesting. It is a bit confusing not so } \\
\text { much clear to reach best solution."(P7) } \\
\text { "I will go neutral for this because according to me it de- } \\
\text { pends on the character of the students. For example girls } \\
\text { can be bored with such a game quicker than boys."(P11) }\end{array}$ \\
\hline $\begin{array}{l}\text { The game aims to increase the } \\
\text { ability of the students in perform- } \\
\text { ing a Life Cycle Assessment } \\
\text { (LCA) competence. Do you think } \\
\text { playing SGM Serious Game and } \\
\text { reflecting on their experience will } \\
\text { help students learn about perform- } \\
\text { ing LCA? }\end{array}$ & $\begin{array}{l}\text { "They can first of all visualize what does it mean, get more } \\
\text { into context rather than just seeing on the paper or listen- } \\
\text { ing to the lecture, and visualization helps them to under- } \\
\text { stand it better." }(P 4) \\
\text { "They cannot see the all aspects of LCA, it is a really big } \\
\text { topic. They can learn something from the game, but not } \\
\text { comprehensive details. What is missing I think is it must be } \\
\text { more comprehensive." }(P 10)\end{array}$ \\
\hline
\end{tabular}


Table 3. (continued)

\begin{tabular}{|c|c|}
\hline $\begin{array}{l}\text { The game aims to increase the } \\
\text { ability of the students in Informa- } \\
\text { tion Gathering competence. Do } \\
\text { you think playing SGM Serious } \\
\text { Game and reflecting on their } \\
\text { experience will help students learn } \\
\text { about Information Gathering? }\end{array}$ & $\begin{array}{l}\text { "Students do not know if the information they gather is } \\
\text { correct or wrong, and this feature can be developed." (P2) } \\
\text { "The dialogues are in primary school level. In the compa- } \\
\text { nies, you do not talk with this language. In the game it is } \\
\text { like some sentences are taken from text books and put as } \\
\text { dialogues. This game does not reflect the real way of com- } \\
\text { munication in business environment." (P3) } \\
\text { "Information gathering seems a bit easy in the game. You } \\
\text { just ask the question and there is an answer, more or less } \\
\text { the same all the time." }(P 8)\end{array}$ \\
\hline $\begin{array}{l}\text { The game aims to increase the } \\
\text { ability of the students in Decision } \\
\text { Making. Do you think playing } \\
\text { SGM Game and reflecting on their } \\
\text { experience will help them learn } \\
\text { about Decision Making? }\end{array}$ & $\begin{array}{l}\text { "The game seems to be mainly on decision making and then } \\
\text { performing LCA but still it is simplified. "(P1) } \\
\text { "At this virtual situation, students will start making deci- } \\
\text { sion" }(P 9) \\
\text { "I am not able to evaluate it." }(P 15)\end{array}$ \\
\hline $\begin{array}{l}\text { Do you think the knowledge ac- } \\
\text { quired and learning outcomes } \\
\text { achieved by your students after } \\
\text { playing SGM Serious Game can } \\
\text { be transferred to other situations? }\end{array}$ & $\begin{array}{l}\text { "Up to now I focused on negative points but to this ques- } \\
\text { tion I will say yes. Because it provides a 3-D environment } \\
\text { as a second life close to reality, you talk to people. I think } \\
\text { it's always good to hear some theory and then to apply } \\
\text { them in practice." }(P 3) \\
\text { "Imagine that you will play this game a thousand times, } \\
\text { and after that u will know how to do an LCA." }(P 12)\end{array}$ \\
\hline $\begin{array}{l}\text { What do you think of SGM Se- } \\
\text { rious Game as a learning tool }\end{array}$ & $\begin{array}{l}\text { "The overall game puts students in real life context al- } \\
\text { though it does not work properly with all the functions but } \\
\text { still it s much better than just sitting in the class and listen- } \\
\text { ing or reading a book about it."(P6) } \\
\text { "Measurement of results does not exist in the game, what } \\
\text { should do student to after computing LCA? Would not it be } \\
\text { better if they were able to discuss results they obtain with } \\
\text { other characters?" }(P 7) \\
\text { "It has a great role to improve the attendance's skills in } \\
\text { making communication." }(P 16)\end{array}$ \\
\hline $\begin{array}{l}\text { What do you think about the future } \\
\text { potential of SGM Serious Game as } \\
\text { a learning tool? }\end{array}$ & $\begin{array}{l}\text { "If it is complete you will have a really good game about } \\
\text { how to conduct an LCA!" (P1) } \\
\text { "If the algorithm behind, I mean details of LCA is im- } \\
\text { proved, it can be a very good tool to be used in the lectures. } \\
\text { Because when you talk about LCA in a lecture, not many } \\
\text { students understand it." (P5) }\end{array}$ \\
\hline
\end{tabular}


Table 3. (continued)

Do you think that playing SGM Serious Game will facilitate learning for your students? Why / why not?

Would you like to use SGM Serious Game in your classroom? Why/why not?

Do you think that context affects learning? What is the typical context of learning for your students? E.g. do they work mostly at home or at university?

To what extent SGM Serious Game will be useful for students whose backgrounds are from different disciplines? E.g. do you think that students with prior knowledge about LCA and students without LCA background can have the same knowledge after playing the game?

How can your students use SGM Serious Game platform most effectively? E.g. playing SGM game in groups or individually

What level of fidelity and immersion has been used in SGM game to support learning activities and outcomes?
"Yes, if new options are provided to let them create their own rules in the beginning of the game." (P5)

"Yes, somehow, but they have to be familiar with this topic." (P14)

"Yes, but now it is difficult. I would say absolutely if we had more time" (P16)

"Yes, but it maybe is difficult because of time limitations because I have other things to teach as well." (P2)

"Right now, it is not very desirable. It has to be improved and definitely it will be used." (P10)

"I would use it but it must be difficult to implement."(P13)

"If it is not confidential, students should play the game themselves at their homes as well and explore different solutions, ways." (P2)

"Absolutely! Where you start learning, how you work. Environment is so important; studying in the kitchen of your place when you have your friends around you is completely different then studying in a library with a $3 D$ game."(P6)

"They might have the same level of knowledge at the end." (P10)

"Absolutely yes, if they simplify the wordings it will be useful. Even if somebody who does not have idea about LCA can play this game and understand things and somehow changes his behavior." (P11)

"It can be applied to more than one specific discipline and if the student is interested he can play no matter what his background is. I think broadly applicable."(P16)

"It is absolutely more effective in teams, because different people have different ideas. Maybe the game can create an environment where students can discuss answers and probably that is the most important thing that can be made in this game." (P9)

"I think they have to play in single players, but they must compete with each other because competing makes it more interesting and interactive."(P14)

"It is very low. Because you achieve the goals very fast. In games, you need to create levels. Maybe in this case, production levels first and then the whole company." (P7)

"To get more involvement, there must be more challenge about how to deal with different characters"

"If complexity is enhanced a bit more I would say that fidelity and immersion would occur more."(P12) 


\section{Conclusion}

The main purpose of this study was to evaluate the effectiveness of SGM game based on teachers' perspective. A deep study was done among 16 teachers at Industrial engineering group of Politecnico di Milano. They have experienced to teach PLM course at graduated level and most of them have used other SGs to teach. They played the first version of the SGM and then each individually took part at a deep interview. In general, teachers mostly believed that game attributes have not been integrated well at SGM, the score was 0.45 out of 1 , and proposed specially to make the virtual environment more similar to reality, however; they optimistically emphasized the potential of SGM to be a supportive learning method.

Players to some extent agreed that SGM helps students to enhance own knowledge of LCA performance. They highlighted the game could not provide enough complicated situation as engineers experience at real industry. The result for the ability of the game to make positive reaction was also demonstrated that teachers found some vague and unclear points that need to be clarified in the further versions. Teachers were not consensus about the ability of SGM to improve information gathering and decision making skills of students. Some teachers believed that pre-determined dialogue tool can enable players to gather enough amount of information and prevent them to be confused. In versus, some criticized pre-determined dialogue due of blacking students' creativity to take different types of decisions. On the other hand, teachers raised the ability of SGM as a learning tool and supportive method at PLM course, while they stressed that it is still far from its maximum potential. Teachers also pinpoint the potential of SGM to provide an environment where students can transfer acquired knowledge and skills in a practical way.

In conclusion, the results provided invaluable information for designer before launching the final version. They were pinpointed by both negative and positive comments. Also teachers were interested to play the final version of SGM in order to be able to decide whether employ it in class. As a technical point, frequent happening problem in dialogue tool made teachers exhausted and consequently influence negatively on their replies. Therefore, solving the technical problems probably will have significant impact on players' interest to be fully engaged in the game.

Acknowledgment. The authors gratefully acknowledge the supports of the EU funded network of excellence Game and Learning Alliance - GALA (ICT-2009258169, www.galanoe.eu) and Transformative, Adaptive, Responsive and enGaging EnvironmenT- TARGET (ICT-2007-231717, www.reachyourtarget.org) and also two MSc students at Politecnico di Milano, Ozan Bagdatli and Cenk Yavuz.

\section{References}

1. Asgari, M., Kaufman, D.: Relationships among computer games, fantasy, and learning. In: Proceedings of the 2nd International Conference on Imagination and Education (retrieved August 15, 2005)

2. Charsky, D.: From Edutainment to serious game: A change in the use of game characteristics. Games and Culture, Sage publication 5(2), 177-198 (2010) 
3. de Freitas, S., Oliver, M.: How can exploratory learning with games and simulations within the curriculum be most effectively evaluated. Computers and Education 46, 249-264 (2006)

4. Garris, R., Ahlers, R., Driskell, J.E.: Games, Motivation and Learning: A Research and Practice Model. Sage Publication 33(4), 441-466 (2002)

5. Gunter, G.A., Kenny, R.F., Vick, E.H.: Taking educational games seriously: using the RETAIN model to design endogenous fantasy into standalone educational games. Journal of Education Tech. Research 56, 511-537 (2008)

6. Hainey, T.: Using Games-based Learning to Teach Requirements Collection and Analysis at Tertiary Education Level. Published Doctoral dissertation (retrieved May 17, 2010)

7. Hague, J.B., Riedel, J., Fradinho, M., Westra, W.: Addressing research fragmentation in serious gaming for manufacturing. In: 14th Workshop of the Special Interest Group (SIG) on Experimental Interactive Learning in Industrial Management, Milan, Italy (June 2010)

8. Kirkpatrick, D.L.: Evaluating training programs: the four levels. Berrett-Koehler, San Francisco (1994)

9. McLean, C., Jain, C.R.S., Lee, Y.T., Riddick, F.: A Simulation and Gaming Architecture for Manufacturing Research, Testing, and Training (2005),

http://www.mel.nist.gov/msidlibrary/doc/nistir7256.pdf

10. Poplin, A.: Playful public participation in urban planning: A case study for online serious games. Journal of Computer, Environment and Urban Systems 36(3), 195-206 (2012)

11. Pourabdollahian, B., Taisch, M., Kerga, E.: Serious Games in Manufacturing Education: Evaluation of Learners' Engagement. In: 4th International Virtual Worlds for Serious Applications Conference. Elsevier Computer Science, vol. 15, pp. 256-265 (2012)

12. Sibbel, A.: Pathways towards sustainability through higher education. International Journal of Sustainability in Higher Education 10(1), 68-82 (2009) 